\title{
Study on Mao Zedong's Methods and Art of Ideological and Political Work
}

\author{
Zhimin Lei \\ School of Marxism, Sichuan Agricultural University, Chengdu, Sichuan, China \\ E-mail: 1007930161@qq.com
}

Keywords: Mao Zedong, Serving the people, Ideological and political work, "feeling", "management" and "system"

\begin{abstract}
Ideological and political work "is the lifeline of economic work and all other work." Today we are decisive in building a well-off society in an all-round way and reviewing "serving the people". We are deeply impressed by Mao Zedong's superb ideological and political work methods and art. He insists on the awareness of purpose, is good at identifying the overall situation, the ideological and political work methods and art that integrate "management" and "system" require us to conscientiously study, study and carry forward and promote the innovation and development of the theory and practice of ideological and political work in the new period.
\end{abstract}

\section{Introduction}

Ideological and political work "is the lifeline of economic work and all other work" ${ }^{[1]}$. It is the central link between uniting the entire Party and the people throughout the country in fulfilling all tasks of the Party and the country and is the fine tradition and political superiority of our Party.

So, how to do ideological and political work? Historical experience tells us that doing a good job of ideological and political work requires not only working principles but more about working methods and art. Mao Zedong is undoubtedly a superb artist of ideological and political work. In 1944, on the eve of the Great Anti-Japanese War, Mao Zedong made a judgment on the situation and delivered a speech entitled "Serving the People" at the memorial service of an ordinary soldier like Zhang Dede. In a short period of 700 words, "serving the people". The basic purpose of the Chinese Communist Party and how to serve the people wholeheartedly, made a concise statement. It fully embodies Mao Zedong's political wisdom of adhering to the awareness of purpose, being good at recognizing the overall situation and choosing the right opportunity, and embodying the fruitful work of political and ideological blending. Today, reviewing the historical and environmental changes before and after its publication and studying and promoting Mao Zedong's methods of ideological and political work will surely provide practical education on how to conscientiously carry out the mass line of the party and enhance the ideological and political leadership of leading cadres. Work level, provide new ideas and new inspiration.

\section{Adhere to the purpose of awareness, good at grasping the overall situation center}

To do a good job in the party's ideological and political work, the first and fundamental issue lies in its ideological and practical consciousness of insisting on serving the people.

The core of serving the people is to uphold the masses' viewpoint that the interests of the people are the highest. Since the day of its birth, the Communist Party of China has constantly enriched its theory and practice to enhance its ideological content. The core idea of Mao Zedong Thought is to serve the people wholeheartedly, and Mao Zedong is the lifelong goal of serving the Chinese people, the fundamental purpose of the Chinese Communist Party. Practitioners, struggles and theorists.

To serve the people is the fundamental purpose of the Chinese Communist Party. The initial interpretation of this fundamental purpose came from a speech entitled "Serving the People" by Mao Zedong in his memorial service in 1944: "Our Communist and Communist Parties lead The Eighth Route Army and the New Fourth Army are members of the revolutionary ranks. "Our team is completely dedicated to liberating the people and is completely working for the benefit of the 
people." [2] For the first time, it systematically expounds the scientific connotation of serving the people in theory. Then, in 1945, he pointed out: "Standing firmly with the Chinese people and serving the Chinese people wholeheartedly is the sole purpose of this army." "We serve the people wholeheartedly and never break away from the masses Starting from the interests of the people, being accountable to the people and being responsible for the leading organs of the Party are all our starting points." On the Seventh Plenary, our party will serve the people wholeheartedly and refer to the height of "the sole purpose of the party," and write it into the party constitution.

Why did Mao Zedong make such a significant and far-reaching remarks at the memorial service of an ordinary party member in 1944 ?

It is not hard to see that Mao Zedong wrote a speech entitled "Serving the People" in 1944, elaborating on the idea of serving the people, Mao Zedong's understanding and political considerations on the current situation and building a better future, The timing of political wisdom and superb ideological and political work methods and art.

From the domestic and foreign perspectives, especially in the domestic situation, the situation is undergoing a new turning point: the situation in the world's anti-fascist war has undergone fundamental changes from 1943 to 1944, and all the major world battlefields have won the turning point of strategic turning points. "In the world anti- After the turning of the Fascist War, the long-term and arduous struggle on the battlefield of the liberated areas under the leadership of the Chinese Communist Party led the Chinese Communist Party to gradually reverse the difficult situation since 1943 and in some areas began to fight against the offensive of Japan and the puppet troops. "[3] As Mao Zedong concluded, "Our base area has been expanded. According to the population of the area, including one side and two sides, it has risen to more than 80 million. There have been another 470,000 troops and 2.27 million militias Party members have grown to more than 900,000. "[4]

In the same year, the battle of the Guomindang on the eastern front of the KMT battlefield failed in the course of the battle such as the Henan, Hunan and Guiyang. The Kuomintang government was in a swing. The CPC and the democratic parties proposed the establishment of a series of democratic nation-building ideas such as the coalition government and the continuous development of the Anti-Japanese Democratic Movement in the Kuomintang. At the same time, objectively providing certain conditions for the CPC to launch central counter-offensive in Central China, South China and North China.

Mao Zedong pointed out new goals and new requirements as early as the Yanan Party's high-level cadre meeting: "The task now is to prepare for the comparison of the more important aspects of the past we must be prepared to launch the Chinese invaded by the Japanese no matter under what circumstances. To make our party capable of such a responsibility, it is necessary to make our party, our army and our base more developed and more consolidated, the work of the city and the thoroughfare must give equal prominence to urban work and base work. "[4] The new task is heavy:" We have led a base of 91 million today, but not enough, But also greater in order to achieve the liberation of the entire nation."[4] And this is the first step of" strengthening urban work and winning the victory of the entire country! "; The second step is more arduous:" We have been in more than 10 years in rural areas, it is necessary to promote familiarity with rural areas and building rural base areas. The party's sixth national congress decided on the task of preparing for the urban uprising, it is impossible to implement it in more than a decade. But now it is different, the resolution of the Sixth National People's Congress must be implemented after the Seventh National People's Congress. Soon after the Seventh National Congress of our Party is possible in this meeting, this congress will discuss issues of strengthening urban work and winning national victory. "[4]

This shows that in the second half of 1944, China was in the crucial stage of the dashing phase in which the war was about to victorious and various difficulties appeared. In particular, it required leaders to sum up experiences and lessons in a timely manner so as to pool the wisdom and strength of the entire party Communists and unite with one another to unite as one Decisive battle to accomplish the central task of the party and obtain the victory of revolution. 
From the point of view of the party, 1944 is the final stage of the rectification movement of the Chinese Communist Party which started in the early 1940s. Through Marxist opposition to subjectivism to rectify the style of study and oppose sectarianism to rectify the style of the party and oppose the " Education campaign, summed up over 20 years of historical experience and lessons, educate the entire party and the cadres and the masses, unify their thinking and understand their unique ideological and political work mechanism, and lay a solid ideological and theoretical foundation for the victory of the Chinese revolution. Service "theory of systematic discourse and preaching to provide a historical basis.

After the political line is established, cadres are the decisive factor. The development and victory of the Chinese revolution depend on the correctness of the party's principles and policies. Under the guidance of the party's ideological and political work, millions of cadres and fighters devote themselves to the interests of the people, bravely struggle against sacrificing and practicing " Serve the people, "the highest purpose of the party. At this moment, however, it is at the turn of the century that a new historic turning point in the war of resistance prevails. It has become an imminent and important task for the Chinese Communist Party to mobilize the Chinese Communists from different hills to make concerted efforts.

Zhang Side, a common soldier born in the Red Fourth Army, was a veteran of life and died in the trials and tribulations of the Long March. He has been loyal to the people sincerely and faithfully loyal to the party. As a grassroots cadre or as a general warrior, he can work hard at his purpose without complaint or complaint. In the former pleasure to be willing to sacrifice, its unknown life, it is supporting the pillars of the future new China Building epitome.

In a casual accident, Zhang Sidao fell in the ordinary job of burning charcoal. As an ordinary warrior, he wrote a battle song dedicated to serving the people in a thrilling zombie spirit. He explained his life to serve the people wholeheartedly The fundamental purpose of this Chinese communist. At the moment of such a new turning point in history in 1944, Zhang Dede's deeds were highly political propaganda values and people's sympathy. Mao Zedong timely grasped the typical case of this ideological and political work and the opportunity of ideological and political education. Combining the advanced nature of the typical figures with the extensive education of the political line, Mao Zedong put forward the well-known thesis of "serving the people" in a clear-cut manner and conducted incisive. The interpretation of the widely proclaimed. Since then, "serving the people" has become the motto of the Chinese Communists and has inspired a batch of Chinese Communists to spare no efforts in the interest of the people.

\section{Make Good Use of "Bridge" and "Ship": Ideological and Political Work Art of Love + Reason + System}

Ideological and political work is an important part of the party's work. To do a good job in ideological and political work has always been a basic work of the party in the field of propaganda. So, how to do this job?

On January 27, 1934, Mao Zedong pointed out in his article "Concerned with People's Livelihood, Paying Attention to Working Methods": "Our task is to cross the river, but we can not cross the bridge without a bridge or without a boat. It is an empty talk. "[5] Mao Zedong compared the solution to the problem to a bridge or ship crossing the river.

Ideological and political work is a complicated systematic project. The first and fundamental issue lies in the ideological and practical consciousness of upholding the fundamental purpose of serving the people. At the same time, we must conform to the times and constantly innovate the ways and means of ideological and political work around the party's central task. This is the "bridge" or "ship" emphasized by Mao Zedong.

From the point of view of innovating the leading art of ideological and political work, it is not difficult to draw such a basic conclusion: Mao Zedong is good at capturing the opportunity of education from the angle of high-rise building and understanding, and making ideological and political Work "love" and "rationale" blend, unite the hearts of the people and unite, pave the way for the completion of the party's main task. 
Because of the success of ideological and political work, first of all come from the soul of the emotional communication and humane care. To this end, we can examine the following details: Details First, Mao Zedong was shocked by Zhang Def's death of non-war, emphasizing the remains of the martyrs to be washed clean, put on new military uniforms; stressed the need to make a good coffin, burial buried; stressed the need to open Memorial service, I want to speak [6]; Details of two, Mao Zedong personally wrote "pay tribute to Comrade Zhang Dede sacrificed for the benefit of the people" and personally wreath sacrificial statue in front of the martyrs, a long silence; detail three, as an ordinary Communist They delivered speeches explaining the significance of sacrificing for the benefit of the people and put forward the historic mission of "providing services to the people" and the foundation of building the party with a sense of heaven and earth. Fourthly, on this speech, Mao Zedong personally Swipe pen to write the key words: to serve the people. Fifthly, from the beginning of the memorial service of Zhang Sideng, I opened up a memorial service for the revolutionary ranks and unite the people with the institutionalized construction to unite the party and the people.

Mao Zedong cherish his life, cherish the soldiers, care for the safety of the masses, and integrate this affection into the calm narration and earnest reasoning: "We should try our best to reduce those unnecessary sacrifices." "In the future, in our ranks, regardless of death No matter who is a cook, a warrior, as long as he has done some useful work, we have to give him a funeral and a memorial service. In this way, we entrust our grief and unite the entire people [2].

Mao Tse-tung's short 700-plus-word speech, blending feelings with reason and profoundly expounding the basic tenet of the Chinese Communists, made an ordinary soldier who lost his life sacrifice his work to serve as an eternal monument to the people in his spirit of "serving the people" Promote solidarity both inside and outside the party and lay a solid mass foundation for the completion of the new tasks in the new phase.

In the meantime, the success of ideological and political work should not only depend on love, but also need to understand rationality and serve people rationally. During the latter part of the war of resistance against Japan, new changes have taken place in the central task and general requirements of our party. In order to accomplish the central task of the party and serve the people wholeheartedly, the greatest political work of the entire party is "unity." In April 1945, Mao Zedong pointed out in his opening address "The Fate of Two Chinas Factions": "We should be modest, cautious, arrogant and impulsive, and serve the Chinese people wholeheartedly. At the present time, in order to unite the nation, People defeat the Japanese aggressors and, in the future, they will build a nation of new democracies for the sake of uniting the entire people. "

To unite the people throughout the country, we must first "unite all the comrades in the party, like a solid steel, for the complete victory of the Anti-Japanese War and for the complete liberation of the Chinese people." 11 At the time It is not necessary to keep abreast of the late rectification movement. During the period from July to August 1943, the work of reviewing and preparing cadres was developed into the "Movement for the Survivor of the Volatile One," with the error of "leftist" and its magnification, which has hurt many revolutionary comrades, especially the Fourth Front Army Who seriously affected the unity of the revolutionary ranks and the central work of the party. Later, Mao Zedong repeatedly reviewed on various occasions, bowed his bow to apologize, made many criticisms and self-criticisms. Zhang Sdek was originally the fourth front army. Mao Zedong seized the opportunity to participate in the memorial service of Zhang Side and made a public speech. He sincerely pointed out: "Because we serve the people, we are not afraid of criticism from others if we have shortcomings. As long as you are right, we will correct the way you say is good for the people and we will follow your example. The opinion that the elite should be simple and concise should be made by Mr. Li Dingming, a non-party person. Well, it is good for the people and we will adopt it. As long as we make good our interests for the people and correct our interests for the benefit of the people, our ranks will surely thrive [2]. " Mao Zedong again and again Self-criticism, resolving the grievances of many people and re-establishing the solidarity among comrades. Chen Ye Ping recalled, "Everyone got a great, infinite comfort, a little bit of melancholy heart, immediately dissolved ice melt solution" [8]. 
Mao Tse-tung said: "Our cadres should care about every soldier and all revolutionary team members should care for each other, and help each other and help each other." [2] Take concrete actions to win people's hearts and safeguard the unity of the revolutionary ranks. "In the future, no matter who died, whether it is a cook, a soldier, as long as he has done some useful work, we have to give him a funeral, a memorial service. This is to become a system. This method should also be introduced to the common people there in this way, Mao Zedong followed his consistent system-building philosophy, stressing that the Communist Party of China must make use of Institutionalized building to unite the ranks, gather the people, and strive to achieve the party's goal.

To sum up, during the revolutionary war, the sacrifice of a soldier is an ordinary thing. However, in the perspective of Mao Zedong's high-spiritedness and social foundation, it is about the party's purpose and style, its unity and its survival, and the liberation of the entire nation; And seize this opportunity to deeply interpret the fundamental purposes of the Chinese Communist Party both inside and outside the Party, show the good tradition of linking theory with practice and criticism and self-criticism of the Chinese Communist Party, unite the party and the public, safeguard and strengthen the unity and unity of the party, and as a generation Mao Zedong great man, his elderly strategic vision far-reaching lofty, indifferent to the working methods, ease, whether the macro-control of the current situation in the field or the micro-world ideological and political work methods and artistic originality are all the Communist Party of China We need to seriously study, study and carry forward so as to promote the innovation and development of the ideological and political theories and practices in the new era.

\section{References}

[1] "Resolution on Certain Historical Issues of the Party since the Founding of the People's Republic of China," In 1981, the 6th Plenary Session of the Eleventh Central Committee of the Communist Party of China.

[2] Mao Zedong: "Serving the People", Selected Works of Mao Zedong, Volume 3, People's Publishing House, June 1991, 2nd Edition, p. 1004, No. 1005 page.

[3] "History of the Communist Party of China," Volume I (1921-1949) the next volume, the CPC History Press, the first 627.

[4] Mao Zedong: "learning and the current situation", "Selected Works of Mao Zedong" Volume III, People's Publishing House 1991, page 944, page 945, bottom 946.

[5] "Selected Works of Mao Zedong" Volume 1, People's Publishing House in 1991 June second edition, the first 139 pages.

[6] Yan'an incident description of China Yanan cadres college page 379.

[7] Resolution on Several Historical Issues, Selected Works of Mao Zedong, Volume 3, People's Press, June 1991, 2nd edition, p. 997.

[8] "Yan'an Central Party School rectification study" second episode, the CPC Central Committee School Press 1987Edition, the first 72 pages. 